\title{
Ortaokul Öğrencilerinin Etkileşimli Tahtaya Yönelik Tutum ve Öğrenme Algıları Üzerine Bir İnceleme
}

\section{A Review on Secondary School Students' Attitudes and Their Perception of Learning Concerning Interactive Whiteboards}

\author{
Mustafa Serkan GÜNBATAR*, Şahin GÖKÇEARSLAN**
}

\begin{abstract}
Öz: Etkileşimli tahtalar, özellikleriyle ve yapılan yatırımlarla dikkat çekmektedir. Bu nedenle araştırmalara konu olmaktadırlar. Bu çalışmada etkileşimli tahta kullanımına yönelik tutum ve etkileşimli tahta ile öğrenme algısı değişkenleri; cinsiyet, sınıf ve öğrenci deneyimleri açısından incelenmiştir. Çalışma, 197 ortaokul öğrencisi ile tarama modelinde gerçekleştirilmiştir. Katılımcılardan 80'i kız 117'si erkektir. Araştırma sonuçlarına göre, etkileşimli tahtaya yönelik olumsuz tutum cinsiyete göre anlamlı düzeyde farklılaşmaktadır. Olumlu tutum sınıf düzeyine göre anlamlı farklılaşmakta, kullanım süresi açısından ise haftalık bir saatten az kullanımının olduğu öğrencilerde anlamlı düzeyde daha düşüktür. Genel tutum açısından ise sınıf düzeyi ve kullanım süresi değişkenleri açısından anlamlı düzeyde farklılaşmaktadır. Etkileşimli tahta ile öğrenme algısı ile ilgili olarak cinsiyete ve sınıf düzeyine göre tüm ölçümler açısından anlamlı farklılaşma görülmüştür. Algılanan negatif etkiler ölçümü haricindeki diğer üç ölçüm açısından da etkileşimli tahta ile haftalık alınan eğitim süresi açısından anlamlı farklılaşma görülmüştür. Etkileşimli tahta kullanım süresi (yıl) açısından ise hem tutum ölçümleri hem de etkileşimli tahta ile öğrenme algısı ölçümleri açısından anlamlı fark yoktur. Benzer çalışmaların lise, üniversite ile öğretmen adayı ve diğer öğrenci gruplarıyla tekrarlanması önerilmektedir. Etkileşimli tahtanın etkileri üzerine çalışmaların yapılması önerilmektedir. Yeniliğin devamlı aynı etkiyi bırakacağı düşüncesinden uzaklaşılmalı, öğrenme etkinlikleri de yeniliklere paralel biçimde geliştirilmelidir.
\end{abstract}

Anahtar Kelimeler: Etkileşimli tahta, tutum, öğrenme algısı, motivasyon, ortaokul öğrencileri

\begin{abstract}
Interactive whiteboards attract attention with their features and investments made thereto. Thusly, these have become subjects of studies. In this study, the attitudes towards using an interactive whiteboard and learning perception by means of interactive whiteboards were investigated in terms of gender, grade level, and student experience variables. The study was performed with 197 secondary school students by means of a survey model. According to the study results, the negative attitudes against interactive whiteboard were differentiated significantly in terms of gender. Positive attitude measurements varied depending significantly on the grade level and were significantly lower for the students who had use of less than one hour in a week in terms of usage period. In terms of general attitude, attitudes were differentiated significantly in terms of grade level variable and usage period variables. Relating to learning perception by means of interactive whiteboards, a difference was seen for all measurements in terms of gender and grade level. There was also a significant difference observed in weekly education period taken with interactive whiteboard from the point of the other three measurements other than the perceived negative effects. There was no significant difference both in terms of the attitude measurements and the learning perception measurements by means of interactive whiteboards with regard to usage period (year) of interactive whiteboards. It is suggested that similar studies are repeated at high school and preservice teachers and other student groups in university. Studies to be conducted on the effect of interactive whiteboard are suggested. The idea that novelty always leaves the same impression should be abandoned, and learning activities should be developed in parallel with novelties.
\end{abstract}

Keywords: Interactive whiteboards, attitude, perception of learning, motivation, secondary school students

\section{Giriş}

Günümüzde sınıf ortamlarında bilişim teknolojileri araçlarının kullanımı giderek yaygınlaşmaktadır. Bu teknolojilerden biri de etkileşimli tahtalardır. Dünya çapında birçok ülkede etkileşimli tahtalar sınıflarda yaygın olarak kullanılmaktadır (Torff ve Tirotta, 2010). Türk eğitim sitemine bilgi ve iletişim teknolojilerinin entegrasyonu sürecinde çeşitli teknoloji yatırımları arasında etkileşimli tahtalar oldukça

\footnotetext{
*Yrd. Doç. Dr.,Yüzüncü Y1l Üniversitesi, Eğitim Fakültesi BÖTE, Van-Türkiye, e-posta: mustafaserkan@ yyu.edu.tr

**Okutman Dr., Gazi Üniversitesi, Enformatik Bölümü, Ankara-Türkiye, e-posta: sgokcearslan@gazi.edu.tr
} 
önemli bir yere sahiptir. (Somyürek, Atasoy ve Özdemir, 2009). Fırsatları Artırma ve Teknolojiyi İyileştirme Hareketi (FATİH) projesi kapsamında 2015 yllsonu itibariyle 289 bin 15 etkileşimli tahta sınıflara kurulmuş olmakla birlikte bu rakamın 347 bin 367 olması için anlaşmalar yapılmıştır (TRT, 2016; MEB, 2015a).

Okul tahtalarının (kara tahta) öğrenme ortamında yer alması eski tarihlere dayanmakla birlikte bu tarihe ilişkin ilk kanıt 1850'lere dayanmaktadır (Hamilton, 1978, aktaran Greiffenhagen, 2002). Elektronik beyaz tahta adı verilen ilk etkileşimli tahtalar başta ofis ortamı için tasarlanmış, eğitim ortamlarında ise ilk defa 90'lı yılların ortalarında üniversitelerde yerini almıştır (Greiffenhagen, 2002). Bilgisayar teknolojisindeki gelişmelerin geleneksel tahtayı değiştirmesi ile etkileşimli tahtalar öğrenme ortamı için çeşitli firsatlar yaratmıştır. Bilgisayar, projeksiyon cihazı, dokunmatik tahta, elektronik kalem ve bazı yazılımların bir araya gelmesi ile oluşan etkileşimli tahta sistemi (Adıgüzel, Gürbulak ve Sarıçayır, 2011) farklı bileşenlerle de üretilebilmektedir. Türkiye Cumhuriyeti Milli Eğitim Bakanlığ FATİH projesi ile sunulan etkileşimli tahta sisteminde ise projeksiyon cihazının yerini entegre bir bilgisayar içeren dokunmatik panel ekran ünitesi almıştır. Bununla birlikte bu etkileşimli panelin yanı sıra, gazlı kalem ve tebeşirin ayrı ayrı kullanıldığı beyaz ve yeşil tahta da bulunmaktadır.

Gündoğdu'ya (2014) göre etkileşimli tahtadaki içerik kaydedilebilmekte ve tekrar kullanılabilmektedir. Böylelikle çizim yapılması veya yazı yazılması esnasında meydana gelen zaman kaybı önlenebilmekte ve öğrencilerin dersten uzaklaşma durumları da azalmaktadır. Kaydedilen içerik veya ders materyali tekrar tekrar kullanılabilmekte, ekran görüntüsü çıktı şeklinde alınabilmekte veya e-posta yoluyla öğrencilere iletilebilmektedir. Etkileşimli tahtanın internete bağlanması ile sınıfın sınırlarının dışına çıkılabilmektedir. Doküman kamerası bağlantısı kurularak da basılı materyaller etkileşimli tahta aracılığıyla yansıtılabilmektedir. Kayıt özelliğinin etkin şekilde kullanımı ile öğrenciler tekrar dinleme olanağı bulabilmektedirler (Levy, 2002). El yazısının bilgisayar yazısına dönüştürülebilmesi, yazının büyütülebilmesi (Smith, 2008) gibi özellikler sayesinde öğrencilerin metni okuması kolaylaşmaktadır. Etkileşimli tahtalar sayesinde birçok medyanın sınıfa taşınması ile derste öğrencilere hitap eden içerikler sunulabilmektedir (Türel, 2010).

Etkileşimli tahtalar öğrencinin derse katılımının sağlanmasına yardımcı olma, başarıyı etkileme (Torff ve Tirotta, 2010), ilgi çekme, heyecan verme ve motivasyon sağlamaya yardımc1 olma (Schmid, 2008), dersi daha iyi kavramaya yardımcı olma (Kaya ve Aydın, 2014) gibi özellikleri nedeniyle öğrenciler ve öğretmenler tarafından tercih edilmektedir. Daha çeşitli ve dinamik kaynakların kullanımını sağlayarak motivasyonu artırmakta ve böylece hem öğretmen hem de ögrencinin dersten daha fazla verim elde etmelerine yardımcı olmaktadır. Ayrıca kişiler arası iletişim ve işbirliğini artırmanın yanı sıra, yaratıcı sunuların yapılmasını sağlamakta, öğrencilerin öz güveni artırmaktadır (Levy, 2002). Bununla birlikte öğrencilere etkileşimli tahta kullanımlarına yönelik firsat tanındığında bu aracın öğrenme sürecini kolaylaştırdığı, görsel öğeleri bünyesinde barındırması özelliği ve bilgiye ulaşmada farklı yolların kullanılması ile konsantrasyon ve dikkat arttırdığı ifade etmektedirler (Wall Higgins ve Smith, 2005). Aşağıda bu araştırmada kullanılan bağımlı ve bağımsız değişkenlere yer verilmiş, eğitiminde teknoloji kullanımı ve duyuşsal özelliklerin yeri etkileşimli tahtalar özelinde tartışılmıştır.

Eğitimde teknoloji kullanımında duyuşsal özellikler önemli bir yer teşkil etmektedir (Venkatesh, 2000; Yang ve Yoo, 2004). Teknoloji entegrasyonu sürecinde çeşitli modeller öne sürülmekle birlikte bu modellerde öğrencilerin tutum, inanç, niyet, motivasyon ve alg1 gibi bireysel faktörlerini farklı biçimlerde ele alınmaktadır (Cakir ve Yildirim, 2009; Mazman ve Usluel, 2011; Türel, 2011) ve bu faktörler kritik öneme sahiptir. Süreçte yönetici, öğretmen öğrenci vb. bireyler yer almakta ve öğrenciler sürecin bir parçasıdır. Öğrencilerin duyuşsal özellikleri teknoloji entegrasyonunda önemli görülmekle birlikte (Mazman ve Usluel, 2011) öğrenmeyi olumlu ya da olumsuz etkilemektedir (Gömleksiz ve Kan, 2012).

$\mathrm{Bu}$ özelliklerden biri eğitim araştırmalarında önemli bir yere sahip olan tutumdur. Tutum kavramı genel olarak bireyin çevresindeki olgu veya nesneye ilişkin var olan tepkisinin eğilimini ifade eder. Bu tepki zihinsel, duygusal ve davranışsal bir harmoniyi bünyesinde barındırmaktadır (İnceoğlu, 2010). Teknoloji araçlarının günümüz eğitim sistemindeki yeri düşünüldüğünde bu teknolojilere yönelik öğrenci tutumlarının belirlenerek, öğretim ortamlarının tasarlanması önemli görülmektedir. Bir teknoloji aracına yönelik tutum, öğrenci başarısı ve diğer değişkenleri etkilemektedir (Cabı, 2016). Öğrencilerin etkileşimli tahtaya yönelik olumsuz tutumları öğrenme ile ilgili birçok değiş̧keni etkileyebilir (Moss, Jewitt, Levaãiç, Armstrong, Cardini ve Castle, 2007). Olumsuz tutum değişiminin zaman alabileceği de 
göz önünde bulundurulursa bu konuda araştırma ve etkinliklerin sürdürülmesi önem arz etmektedir.

Teknoloji kullanımında motivasyon bir diğer duyuşsal özellik olarak karşımıza çıkmaktadır. Motivasyon öğrencinin öğrenme etkinliklerinde etkin olarak yer alması ve onun bu sürece katılmaya istekliliğinin derecesi olarak ifade edilmektedir (Kelecioğlu, 1992). İçsel, dışsal ve öğrenme motivasyonu biçiminde üç tür motivasyondan bahseden Lumsden (1994), motivasyonun öğrencinin öğrenme etkinliklerine yer alma isteği ve bunun altında yatan nedenlerle ilgili olduğunu belirtmiştir. Etkileşimli tahta kullanımının motivasyonu artırdığı ifade edilmektedir (Akgün ve Koru, 2015; Mercer, Warwick, Kershner ve Kleine Staarman, 2010; Wall ve diğerleri, 2005; Schmid, 2008). Matematik öğretiminde etkileşimli tahta kullanımının öğrenci motivasyonunu artırdığı belirtilmiştir (Torff ve Tirotta, 2010). Bununla birlikte etkileşimli tahtanın öğrenci motivasyonu üzerine etkisi ile ilgili çalışmaların sürdürülmesi önerilmektedir (Torff ve Tirotta, 2010).

Teknoloji ve öğrenme bağlamında bir diğer duyuşsal özellik algıdır. Öğrenci algıları teknoloji entegrasyonunda önemli bir yere sahiptir (Davis, 1989; Saadé ve Bahli, 2005). Algılanan öğrenme, sınıftaki teknoloji kullanımında karşılaşılan önemli duyuşsal özellikler arasında yer almaktadır (Baylor ve Ritchie, 2002). Algılanan öğrenme, "öğrencinin içsel değişim sürecinden elde ettiği çıktılar ve ürünleri kendisinin değerlendirmesi” olarak ifade edilmektedir. Bir öğrenme sürecine yönelik inanç ve duyguların bütünü olarak belirtilen bu kavram ders başarısının öğrenci tarafından değerlendirilmesini sağlamada kullanılan sınav sonuçlarından daha etkili bir bilgi olduğu ileri sürülmektedir (Albayrak, Güngören ve Horzum, 2014). Algılanan öğrenmenin araştırmalarda sınırlı sayıda çalışıldığı ifade edilmekle birlikte (Albayrak ve diğerleri, 2014), özellikle öğrencilerin etkileşimli tahtaya ile işlenen derse yönelik öğrenme algısı alanyazında birkaç çalışmada karşımıza çıkmaktadır (Aytaç, 2013; Öz, 2014). Etkileşimli tahta kullanılan dersin etkililiğinin ölçülmesi bu teknolojinin olumlu ve olumsuz yanlarının belirlenmesi bakımından önemlidir. Yukarıda da ifade edildiği üzere duyuşsal özellikler eğitimde teknolojinin etkili biçimde kullanımı için anahtar bir role sahiptir. Etkileşimli tahtalar üzerine temellendirilmiş duyuşsal özelliklerin çalışmalarla desteklenmesinde fayda görülmektedir.

Araştırmanın bağımsız değiş̧kenlerini cinsiyet, sınıf düzeyi, öğrenci deneyimi ve etkileşimli tahta kullanım süresi oluşturmaktadır. Cinsiyet değişkeninin etkileşimli tahta kabulünde moderatör etkiye sahip olduğu ifade edilmekle birlikte (Tosuntaş, Karadağ ve Orhan, 2015), etkileşimli tahta ile ilgili çalışmalarda cinsiyet değişkeninin yer alması önerilmektedir (DiGregorio ve Sobel-Lojeski, 2010). Bununla birlikte Luo ve Yang (2016) öğrencilerin etkileşimli tahta kullanımına yönelik deneyimlerinin etkileşimli tahta kullanım istekliliği için önemli bir değişken olduğunu ifade etmiştir. Aytaç (2013) bu deneyimlerden biri olan sınıf düzeyi bakımından etkileşimli tahta kullanımının değiştiğini belirtilmiştir. Özellikle öğrencilerin etkileşimli tahtalarla ilgili bakış açısını ortaya koyacak çalışmalar alanda sınırlı sayıdadır (Aytaç, 2013; Çakıroğlu, 2016). Öğrencilerin duyuşsal özellikleri öğrenme için önemli görülmekle birlikte, bu duyuşsal özelliklerin değiştirilmesi zaman alacaktır. Bu konuda yukarıda belirtilen değişkenleri kapsayan özellikle ortaokul öğrenci grubu ile gerçekleştirilmiş çalışmaların sınırlı sayıda olması bu araştırmanın yapılmasının temel nedeni olmuştur. FATİH projesi kapsamında Milli Eğitim Bakanlığı devlet ortaokullarında etkileşimli tahtaların kullanımı ikinci faz ikinci kısım olarak tabir edilen dönemde 2015-2016 öğretim y1lında başlamıştır (MEB, 2015b). Özel okullar etkileşimli tahtayı daha önce kullanmaya başlamıştır. $\mathrm{Bu}$ bağlamda araştırma sonuçlarının gelecekteki uygulamalara 1şık tutacağı düşünülmektedir. Bu çalışmanın amacı, etkileşimli tahta kullanımına yönelik duyuşsal özelliklerden tutum, algılanan öğrenme ve motivasyon, algılanan etkililik ve negatif etkiler değişkenlerinin cinsiyet, sınıf düzeyi, öğrenci deneyimi, etkileşimli tahta kullanım süresi değişkenlerine göre anlamlı farklılaşma durumunu ortaya koymaktır.

\section{Yöntem}

\section{Araştırma Modeli}

$\mathrm{Bu}$ çalışmada ortaokul öğrencilerinin etkileşimli tahtaya yönelik tutumları ve etkileşimli tahta ile öğrenme algıları tespit edilmiş, etkileşimli tahta tutumunun ve etkileşimli tahta ile öğrenme algılarının cinsiyet, sınıf ve öğrenci deneyimi değişkenlere göre farklılaşıp farklılaşmadığı belirlenmiştir. Çalışma grubu öğrencilerine ilişkin veriler var olduğu şekliyle betimlendiği ve karşılaştırma yolu ile ilişki çözümlemeleri yapıldığı için araştırma genel tarama modelindedir (Karasar, 2005).

\section{Çalışma Grubu}

Çalışma kapsamında elde edilen veriler 2014-2015eğitim öğretim yılında Ankara ilinden iki özel 
ortaokulda öğrenim gören öğrencilerinden elde edilmiştir. Araştırma için bu grubun seçilme nedeni araştırmanın yapıldığı tarihlerde etkileşimli tahtaya özel okulların sahip olmasıdır. Verilerin toplandığı okullardaki etkileşimli tahtalar FATİH projesi kapsamında kurulan tahtalardan değildir. Tüm sınıflarında okulların kendi imkanları ile edindiği etkileşimli tahta teknolojisi bulunmaktadır. $\mathrm{Bu}$ teknolojiden faydalanma durumu ise öğretmenlerin tercihleri doğrultusunda olmaktadır. Toplam 197 öğrenciden elde edilen verilerle analizler gerçekleştirilmiştir. Katılımcılardan 80'i kız 117'si erkektir. 66'1 (\%33.5) 6. sinıfa, 63’ü (\%32) 7. sinıfa, 68'i (\%34.5) 8. sinıfa devam etmektedir. Tablo 1'de katılımcılara ilişkin demografik özellikler sunulmuştur.

Tablo 1

Katılımcılara İlişkin Demografik Özellikler

\begin{tabular}{|c|c|c|c|c|c|c|}
\hline & & & \multicolumn{3}{|c|}{ Sinif } & \multirow[t]{2}{*}{ Toplam } \\
\hline & & & 6.sinif & 7.sinif & 8.sinif & \\
\hline \multirow{6}{*}{ Cinsiyet } & \multirow{2}{*}{$\mathrm{K} 1 \mathrm{Z}$} & $\mathrm{N}$ & 28 & 23 & 29 & 80 \\
\hline & & $\%$ & 35.0 & 28.7 & 36.2 & 100 \\
\hline & \multirow{2}{*}{ Erkek } & $\mathrm{N}$ & 38 & 40 & 39 & 117 \\
\hline & & $\%$ & 32.5 & 34.2 & 33.3 & 100 \\
\hline & \multirow{2}{*}{ Toplam } & & 66 & 63 & 68 & 197 \\
\hline & & $\%$ & 33.5 & 32.0 & 34.5 & 100 \\
\hline
\end{tabular}

\section{Veri Toplama}

Etkileşimli Tahta Tutum Ölçeği. Araştırma kapsamında katılımcıların etkileşimli tahtaya yönelik tutumlarını belirlemek için Şad (2012) tarafından geliştirilen 10 maddelik Etkileşimli Tahta Tutum Ölçeği kullanılmıştır. Ölçek beşli likert tiptedir. Her madde için katılımcılar "Kesinlikle katılıyorum (5)", "Katıliyorum (4)", "Az katıliyorum (3)", "Katılmıorum (2)","Kesinlikle katılmıorum (1)" ifadeleri için değerlendirme yapmıştır. Ölçeğin iki alt boyutu bulunmaktadır. Birinci faktör olumsuz tutum ifadelerini, ikinci faktör olumlu tutum ifadelerini kapsamaktadır. 1, 4, 7, 8 ve 9. maddeler olumsuz tutum boyutunu oluşturmaktadır. $\mathrm{Bu}$ maddelerin faktör yük değerleri 0.821 ile 0.680 arasında değişmektedir. 2, 3, 5, 6 ve 10. maddeler olumlu tutum ifadelerini barındıran ikinci faktörü oluşturmaktadırlar. İkinci faktör kapsamındaki maddelerin yük değerleri 0.826 ile 0.682 arasında değerler almaktadır. Ölçme aracı toplam varyansın \% 60. 46'sını açıklamaktadır. İki boyutlu olan ölçeğin uyum iyiliği değerleri mükemmel ve kabul edilebilir sınırları içerisindedir. Ölçeğin Cronbach Alfa iç tutarlılık katsayısı 1. faktör için $\alpha=0.816$ ve 2 . Faktör için $\alpha=0.821$ 'dir. Guttman iki yarı güvenirlik katsayıs1 1. faktör için 0.811 ve 2 . faktör için 0.768 olarak rapor edilmiştir. Madde toplam korelasyonları 0.702 ve 0.547 arasında değişen değerler almıştır. Bununla birlikte test-tekrar test kararlılık katsayısı 1.faktör için $r=0.885,2$. faktör için $r=0.883$ olarak hesaplanmıştır. Ölçeğin bu çalışma kapsamında kullanılması sonucunda olumsuz tutum alt faktörünün Cronbach Alfa iç tutarlılık katsayısı $\alpha=0.775$; olumlu tutum faktörünün Cronbach Alfa iç tutarlılık katsayısı $\alpha=0.895$; ölçeğin tamamı için Cronbach Alfa iç tutarlılık katsayısı $\alpha=0.805$ olarak bulunmuştur.

Etkileşimli Tahta ile Öğrenme Algısı Ölçeği. Çalışmaya katılan öğrencilerin etkileşimli tahta ile öğrenme algılarını belirleyebilmek amacıyla Türel (2011) tarafindan geliştirilen ölçek kullanılmıştır. Ölçek üç alt boyuttan ve toplam 26 maddeden oluşmaktadır. Öğrenciler her madde için "Kesinlikle katıliyorum (5)", "Katılıyorum (4)", "Kararsızım (3)", "Katılmıyorum (2)", "Kesinlikle katılmıyorum (1)" ifadeleri için değerlendirme yapmıştır. 18 maddeden oluşan "Algılanan öğrenmeye katkı ve motivasyon", 5 maddeden oluşan "Algıllanan etkililik" ve 3 maddeden oluşan "Algılanan negatif etkiler" şeklinde üç alt boyutu bulunmaktadır. Ölçek maddelerinin yük değerleri 0.802 ile 0.448 arasında değişmektedir. Üç faktörlü yapısı ile ölçek toplam varyansın \% 50.166'sını açıklamaktadır. Birinci faktör için Cronbach Alfa iç tutarlılık katsayısı $\alpha=0.952$, ikinci faktör için $\alpha=0.737$, üçüncü faktör için $\alpha=0.654$ bulunmuştur. 26 maddelik ölçeğin tamamının Cronbach Alfa iç tutarlılık katsayısı $\alpha=0.94$ ' tür. Ölçeğin bu çalışmadaki algılanan öğrenmeye katkı ve motivasyon alt boyutuna ilişkin Cronbach Alfa iç tutarl11ık katsayısı $\alpha=0.973$; algılanan etkililik alt boyutuna ilişkin Cronbach Alfa iç tutarlılık katsayısı $\alpha=0.798$; algılanan negatif etkiler Cronbach Alfa iç tutarlılık katsayısı $\alpha=0.813$; ölçeğin tamamının Cronbach Alfa iç tutarlılık katsayısı $\alpha=0.960$ olarak bulunmuştur. 


\section{Verilerin Analizi}

Çalışma kapsamında öğrencilerin etkileşimli tahtaya yönelik tutumları ve etkileşimli tahta ile öğrenme algıları; cinsiyet, öğrenim görülen sınıf düzeyi, etkileşimli tahtanın haftalık kullanım süresi ve kaç yıldır etkileşimli tahta kullanıldığına göre farklılık gösterip göstermediğine ilişkin olarak sınanmıştır. Öğrencilerin etkileşimli tahtaya yönelik tutumları ve tutum ölçeği alt faktör (olumsuz tutum, olumlu tutum) puanları bağımlı değişkenler olarak alınmıştır. Ardından sırasıyla cinsiyet, öğrenim görülen sınıf düzeyi, sınıf ortamında etkileşimli tahtanın haftalık ortalama kullanım süresi ve kaç yıldır etkileşimli tahta kullanıldığına ilişkin veriler bağımsız değişkenler olarak alınarak tek yönlü gruplar arası çok değişkenli varyans analizi (MANOVA) gerçekleştirilmiştir. Benzer şekilde öğrencilerin etkileşimli tahta ile öğrenme algı puanları ve ölçeğin alt faktörleri (Algılanan öğrenmeye katkı ve motivasyon, algılanan etkililik, algılanan negatif etkiler) bağımlı değişkenler olarak alınmış; sırasıyla cinsiyet, öğrenim görülen sınıf düzeyi, etkileşimli tahtanın haftalık kullanım süresi ve kaç yıldır etkileşimli tahta kullanıldığına ilişkin veriler bağımsız değişkenler olarak alınarak tek yönlü gruplar arası çok değişkenli varyans analizi (MANOVA) gerçekleştirilmiştir.

\section{Bulgular}

Öğrencilerin etkileşimli tahtaya yönelik tutumlarının ve etkileşimli tahta ile öğrenme algılarının; cinsiyet, öğrenim görülen sınıf düzeyi, etkileşimli tahtanın haftalık kullanım süresi ve kaç yıldır etkileşimli tahta kullanıldığına göre anlamlı bir farklı1ık gösterip göstermediği aşağıda sunulmuştur.

\section{Etkileşimli Tahtaya Yönelik Tutuma İlişkin Bulgular}

Etkileşimli Tahtaya Yönelik Tutum ve Alt Boyutlarının Cinsiyete Göre Karşılaştırılmasına İlişkin Bulgular.

Kız ve erkek öğrencilerin etkileşimli tahta tutumlarının farklı boyutlardaki ölçümleri araştırılmıştır. Öğrencilerin etkileşimli tahtaya yönelik tutumlarının cinsiyete göre farklılaşma durumunun tespiti için tek yönlü gruplar arası çok değişkenli varyans analizi gerçekleştirilmiştir. Olumsuz tutum, olumlu tutum ve toplam tutum puanı olmak üzere üç bağımlı değişken dikkate alınmıştır. Bağımsız değişken ise cinsiyettir. MANOVA testinin normallik (normality), doğrusallık (linearity), tek değişkenlilik (univariate) ve çok değişkenli (multivariate) uç değerler, varyans-covaryans matrislerinin homojenliği ve eşdüzlemlilik varsayımları test edilmiş ve bunları sağladığı görülmüştür. Bağımlı değişkenlerin ortak etkisine göre kız ve erkek öğrenciler arasında anlamlı farklılık bulunmuştur $\left(\mathrm{F}_{(2,194)}=9.41, \mathrm{p}=0.000\right.$; Wilks' Lambda $(\wedge)=0.91$; Partial eta squared $=0.088)$.

Tablo 2

Etkileşimli Tahtaya Yönelik Olumsuz Tutum, Olumlu Tutum ve Toplam Tutum Puanlarının Cinsiyete Göre Ortalama, Standart Sapma Değerleri ve ANOVA Sonuçları

\begin{tabular}{lllllllll}
\hline & Cinsiyet & $\mathrm{N}$ & $\bar{x}$ & $\mathrm{Ss}$ & $\mathrm{Sd}$ & $\mathrm{F}$ & $\mathrm{p}$ & Partial eta squared \\
\hline Olumsuz tutum & K1z & 80 & 1.76 & 0.83 & $1-195$ & 14.15 & 0.000 & 0.068 \\
& Erkek & 117 & 2.24 & 0.90 & & & & \\
\hline Olumlu tutum & Kiz & 80 & 3.49 & 1.20 & $1-195$ & 1.85 & 0.175 & 0.009 \\
& Erkek & 117 & 3.71 & 1.07 & & & & \\
\hline \multirow{2}{*}{ Toplam tutum } & Kiz & 80 & 3.86 & 0.82 & $1-195$ & 1.27 & 0.261 & 0.006 \\
& Erkek & 117 & 3.74 & 0.75 & & & & \\
\hline
\end{tabular}

Cinsiyet değişkenine göre yapılan tek yönlü ANOVA sonuçları Tablo 2'de sunulmuştur. Buna göre etkileşimli tahtaya yönelik olumsuz tutum puanları cinsiyete göre anlamlı farklılık gösterirken $\left(\mathrm{F}_{(1,195)}=14.15, \mathrm{p}=0.000\right.$, Partial eta squared $=0.068$. $)$; olumlu tutum $\left(\mathrm{F}_{(1,195)}=1.85\right.$, $\mathrm{p}>0.05$, Partial eta squared $=0.009)$ ve toplam tutum $\left(\mathrm{F}_{(1,195)}=1.27, \mathrm{p}>0.05\right.$, Partial eta squared $\left.=0.006\right)$ puanlar1 arasinda anlamlı bir fark bulunmamıştır. Ortalama puanlar göz önünde bulundurulduğunda olumsuz tutum puanı ortalamalarının erkeklerde $(\bar{x}=2,24, \mathrm{Ss}=0.90)$ kızlara göre $(\bar{x}=1,76, \mathrm{Ss}=0.83)$ anlamlı düzeyde daha yüksek olduğu görülmüştür.

Etkileşimli Tahtaya Yönelik Tutum ve Alt Boyutlarının Öğrenim Görülen Sinlf Düzeyine Göre 
Karşılaştırılmasına İlişkin Bulgular.

Öğrenim görülen sınıf değişkenine göre öğrencilerin etkileşimli tahtaya yönelik tutumları ve alt faktörlerine ilişkin ölçümleri karşılaştırılmıştır. Bunun için tek yönlü gruplar arası çok değişkenli varyans analizi gerçekleştirilmiştir. Bağımlı değişkenler olumsuz tutum, olumlu tutum ve toplam tutum puanı şeklinde dikkate alınmıştır. Bağımsız değişkenler ise öğrenim görülen sınıf düzeyleridir. Olumsuz tutum, olumlu tutum ve toplam tutum puanı değişkenlerinin ortak etkisine göre sınıf düzeyi açısından anlamlı farklılık tespit edilmiştir $\left(\mathrm{F}_{(4,386)}=8.11, \mathrm{p}=0.000\right.$; Wilks' Lambda $(\wedge)=0.85$; Partial eta squared $=0.078$ ).

Tablo 3

Etkileşimli Tahtaya Yönelik Olumsuz Tutum, Olumlu Tutum ve Toplam Tutum Puanlarının Sınıf Düzeyine Göre Ortalama, Standart Sapma Değerleri ve ANOVA Sonuçları

\begin{tabular}{lllllllll}
\hline & Sinif & $\mathrm{N}$ & $\bar{x}$ & $\mathrm{Ss}$ & $\mathrm{Sd}$ & $\mathrm{F}$ & $\mathrm{p}$ & $\begin{array}{l}\text { Partial eta } \\
\text { squared }\end{array}$ \\
\hline Olumsuz tutum & 6. sinif & 66 & 1.98 & 0.89 & $2-194$ & 0.71 & 0.493 & 0.007 \\
& 7. sinif & 63 & 2.16 & 0.83 & & & & \\
& 8. sinif & 68 & 2.01 & 0.97 & & & & \\
\hline Olumlu tutum & 6. sinif & 66 & 4.00 & 0.79 & $2-194$ & 15.35 & 0.000 & 0.137 \\
& 7. sinif & 63 & 3.83 & 0.92 & & & & \\
& 8. sinif & 68 & 3.06 & 1.34 & & & & \\
\hline Toplam tutum & 6. sinif & 66 & 4.01 & 0.72 & $2-194$ & 7.26 & 0.001 & 0.070 \\
& 7. sinif & 63 & 3.83 & 0.74 & & & & \\
& 8. sinif & 68 & 3.52 & 0.80 & & & & \\
\hline
\end{tabular}

Sınıf düzeyine göre yapılan tek yönlü ANOVA sonuçları Tablo 3'te sunulmuştur. Buna göre anlamlı farkl1lığın olumlu tutum alt faktöründe $\left(\mathrm{F}_{(2,194)}=15.35, \mathrm{p}=0.000\right.$, Partial eta squared $\left.=0.137\right)$ ve tutum toplam puanı için söz konusu olduğu $\left(\mathrm{F}_{(2,194)}=7.26, \mathrm{p}<0.05\right.$, Partial eta squared $\left.=0.07\right)$ görülmüştür. Yapılan çoklu Bonferroni karşılaştırma testi sonucuna göre farkın olumlu tutum alt faktörü için 6-8 ve $7-8$ sinıflar arasında olduğu $(\mathrm{p}<0.05)$; toplam tutum için ise 6-8 sınıflar arasında olduğu tespit edilmiştir $(\mathrm{p}<0.05)$.

Etkileşimli Tahtaya Yönelik Tutum ve Alt Boyutlarının Etkileşimli Tahtanın Haftalık Kullanım Süresine Göre Karşılaştırılmasına İlişkin Bulgular.

Etkileşimli tahtanın haftalık kullanım süresine göre öğrencilerin etkileşimli tahtaya yönelik tutumları ve alt faktörlerine ilişkin ölçümleri karşılaştırıldığında olumsuz tutum, olumlu tutum ve toplam tutum puanı değişkenlerinin ortak etkisine göre etkileşimli tahtanın haftalık kullanım süresi açısından anlamlı farkl1lik tespit edilmiştir $\left(\mathrm{F}_{(8,382)}=3.85, \mathrm{p}=0.000\right.$; Wilks' Lambda $(\wedge)=0.86$; Partial eta squared $\left.=0.075\right)$.

Bağımlı değişkenlerin sonuçları ayrı ayrı değerlendirilmiş ve Tablo 4'te sunulmuştur. Olumlu tutum ortalama puanları $\left(\mathrm{F}_{(4,192)}=6.55, \mathrm{p}=0.000\right.$, Partial eta squared $\left.=0.120\right)$ ve tutum toplam puanlar1 açısından $\left(\mathrm{F}_{(4,192)}=7.03, \mathrm{p}=0.000\right.$, Partial eta squared $\left.=0.128\right)$ anlamlı farklılaşmanın olduğu görülmüştür. Olumlu tutum puan ortalamaları üzerinde yapılan Bonferroni çoklu karşılaştırma testi, haftalık bir saatten az etkileşimli tahta kullanımının olduğu öğrencilerle 1-3 saat arası, 4-5 saat arası ve 8 saatten fazla kullanımın olduğu öğrenciler arasında anlamlı farklılaşmanın olduğunu ortaya koymuştur $(\mathrm{p}<0,05)$. Haftalık 1 saatten az etkileşimli tahta ile öğrenim gören öğrencilerin olumlu tutum puan ortalamalar1 $(\bar{x}=3.02), 1-3$ saat aras $(\bar{x}=3.86), 4-5$ saat aras1 (4.02) ve 8 saatten fazla $(\bar{x}=3.91)$ etkileşimli tahta ile eğitim alan öğrencilere göre anlamlı düzeyde düşüktür $(\mathrm{p}<0.05)$. Tutum ortalama puanları için yapılan Bonferroni çoklu karşılaştırma testi sonucuna göre ise etkileşimli tahtanın bir saatten az kullanıldığı sinıflarda öğrenim gören öğrencilerin ortalama puanları $(\bar{X}=3.35)$ diğer dört gruptan $(1-3$ saat $\bar{x}=3.91 ; 4-5$ saat $\bar{x}=4.05 ; 6-7$ saat $\bar{x}=3.92 ; 8$ saatten fazla $\bar{x}=4.03)$ anlaml düzeyde düşüktür $(\mathrm{p}<0.05)$. 
Tablo 4

Etkileşimli Tahtaya Yönelik Olumsuz Tutum, Olumlu Tutum ve Toplam Tutum Puanlarının Haftalık Etkileşimli Tahta Kullanım Süresine Göre Ortalama, Standart Sapma Değerleri ve ANOVA Sonuçları

\begin{tabular}{lllllllll}
\hline & $\begin{array}{l}\text { Haftalik } \\
\text { kullanim }\end{array}$ & $\mathrm{N}$ & $\bar{x}$ & $\mathrm{Ss}$ & $\mathrm{Sd}$ & $\mathrm{F}$ & $\mathrm{p}$ & $\begin{array}{l}\text { Partial eta } \\
\text { squared }\end{array}$ \\
\hline Olumsuz tutum & 1 saatten az & 57 & 2.31 & 1.06 & $4-192$ & 2.09 & 0.084 & 0.042 \\
& 1-3 saat & 60 & 2.02 & 0.86 & & & & \\
& 4-5 saat & 30 & 1.92 & 0.89 & & & & \\
& 6-7 saat & 33 & 1.83 & 0.70 & & & & \\
& 8 saatten fazla & 17 & 1.85 & 0.70 & & & & \\
\hline Olumlu tutum & 1 saatten az & 57 & 3.02 & 1.39 & $4-192$ & 6.55 & 0.000 & 0.120 \\
& 1-3 saat & 60 & 3.86 & 0.98 & & & & \\
& 4-5 saat & 30 & 4.02 & 0.89 & & & & \\
& 6-7 saat & 33 & 3.68 & 0.80 & & & & \\
& 8 saatten fazla & 17 & 3.91 & 0.82 & & & & \\
\hline Toplam tutum & 1 saatten az & 57 & 3.36 & 0.78 & $4-192$ & 7.03 & 0.000 & 0.128 \\
& 1-3 saat & 60 & 3.92 & 0.73 & & & & \\
& 4-5 saat & 30 & 4.05 & 0.77 & & & & \\
& 6-7 saat & 33 & 3.92 & 0.65 & & & & \\
8 saatten fazla & 17 & 4.04 & 0.72 & & & & \\
\hline
\end{tabular}

Etkileşimli Tahtaya Yönelik Tutum ve Alt Boyutlarının Etkileşimli Tahta ile Eğitim Alınma Süresine Göre Karşılaştırılmasina İlişkin Bulgular.

Kaç yıldır etkileşimli tahta ile eğitim alındığı ile etkileşimli tahta tutumları ve alt faktörlerine ilişkin ölçümleri karşılaştırıldığında; olumsuz tutum, olumlu tutum ve toplam tutum puanı değişkenlerinin ortak etkisine göre kaç yıldır etkileşimli tahta ile eğitim alınması durumu anlamlı farklılık göstermemektedir $\left(\mathrm{F}_{(12,378)}=0.84, \mathrm{p}>0.05\right.$; Wilks' Lambda $(\wedge)=0.95$; Partial eta squared=0.026). Bağımsız değişkenlerin ölçümleri ayrı ayrı analize tabi tutulduğunda da benzer şekilde etkileşimli tahta ile eğitim alınma süresine göre anlamlı farklılaşma olmadığı görülmüştür (p>0.05).

\section{Etkileşimli Tahta ile Öğrenme Algısına İlişkin Bulgular}

Etkileşimli Tahta ile Ögrrenme Algısı ve Alt Boyutlarının Cinsiyete Göre Karşılaştırılmasına İlişskin Bulgular.

Öğrencilerin etkileşimli tahta ile öğrenme algılarının cinsiyete göre farklılaşma durumunun tespiti için tek yönlü gruplar arası çok değişkenli varyans analizi gerçekleştirilmiştir. Algılanan öğrenmeye katkı ve motivasyon, algılanan etkililik, algılanan negatif etkiler ve toplam puan olmak üzere dört bağımlı değişken dikkate alınmıştır. Bağımsız değişken ise cinsiyettir. Bağımlı değişkenlerin ortak etkisine göre k1z ve erkek öğrenciler arasında anlamlı farklılık yoktur $\left(\mathrm{F}_{(3,193)}=1.96, \mathrm{p}>0.05\right.$; Wilks' $\operatorname{Lambda}(\wedge)=$ 0.97; Partial eta squared $=0.03$ ).

Bağımlı değişken puanları ayrı ayrı incelendiğinde ise algılanan negatif etki alt boyutunda cinsiyete göre anlamlı düzeyde farklılaşmanın olduğu görülmüştür $\left(\mathrm{F}_{(1,195)}=4.383, \mathrm{p}<0.05\right.$, Partial eta squared $=0.022)$ (Tablo 5). Ortalama puanlar göz önünde bulundurulduğunda bu boyuta ilişkin kız öğrencilerin $(\bar{x}=3.28)$ erkek öğrencilere $(\bar{x}=2.89)$ göre daha yüksek puana sahip oldukları görülmüsstür. 
Tablo 5

Etkileşimli Tahta ile Öğrenme Algısı Toplam Puanı ve Alt Faktör Puanlarının Cinsiyete Göre Ortalama, Standart Sapma Değerleri ve ANOVA Sonuçları

\begin{tabular}{lllllllll}
\hline & Cinsiyet & $\mathrm{N}$ & $\bar{x}$ & $\mathrm{Ss}$ & $\mathrm{Sd}$ & $\mathrm{F}$ & $\mathrm{p}$ & $\begin{array}{l}\text { Partial } \\
\text { eta } \\
\text { squared }\end{array}$ \\
\hline $\begin{array}{l}\text { Algilanan öğrenmeye katk1 ve } \\
\text { motivasyon }\end{array}$ & $\mathrm{Kiz}$ & 80 & 3.62 & 1.22 & $\begin{array}{l}1- \\
195\end{array}$ & 0.023 & 0.879 & 0.000 \\
& Erkek & 117 & 3.60 & 1.08 & & & & \\
\hline Algilanan etkililik & Kiz & 80 & 3.59 & 1.07 & $1-95$ & 0.053 & 0.819 & 0.000 \\
& Erkek & 117 & 3.55 & 0.97 & & & & \\
\hline Algilanan negatif etkiler & Kiz & 80 & 3.28 & 1.29 & $1-$ & 4.383 & 0.038 & 0.022 \\
& Erkek & 117 & 3.90 & 1.25 & 195 & & & \\
\hline Toplam puan & Kiz & 80 & 3.50 & 1.06 & $1-95$ & 0.021 & 0.885 & 0.000 \\
& Erkek & 117 & 3.53 & 0.92 & & & & \\
\hline
\end{tabular}

Etkileşimli Tahta ile Öğrenme Algısı ve Alt Boyutlarının Öğrenim Görülen Sinıf Düzeyine Göre Karşılaş̧tırılmasına İlişkin Bulgular.

Öğrenim görülen sınıf düzeyi açısından, etkileşimli tahta ile öğrenme algısı puanı ve alt faktörlerine göre farklılaşma durumunun tespiti için MANOVA analizi yapılmıştır. Algılanan öğrenmeye katkı ve motivasyon, algılanan etkililik, algılanan negatif etkiler ve toplam puan bağımlı değiş̧kenlerdir. Bağımlı değişkenlerin ortak etkisine göre anlamlı farklılık tespit edilmiştir $\left(\mathrm{F}_{(6,384)}=6.57\right.$, $\mathrm{p}=0.000$; Wilks' Lambda $(\wedge)=0.82$; Partial eta squared $=0.093)$.

Tablo 6

Etkileşimli Tahta ile Öğrenme Algısı Toplam Puanı ve Alt Faktör Puanlarının Öğrenim Görülen Sınıf Düzeyine Göre Ortalama, Standart Sapma Değerleri ve ANOVA Sonuçları

\begin{tabular}{lllllllll}
\hline & Sinif & $\mathrm{N}$ & $\bar{x}$ & $\mathrm{Ss}$ & $\mathrm{Sd}$ & $\mathrm{F}$ & $\mathrm{p}$ & Partial eta squared \\
\hline Algilanan & 6. sinıf & 66 & 3.97 & 0.83 & $2-194$ & 15.50 & 0.000 & 0.138 \\
ögrenmeye & 7. sinıf & 63 & 3.83 & 0.90 & & & & \\
$\begin{array}{l}\text { katk1 ve } \\
\text { motivasyon }\end{array}$ & 8. sinıf & 68 & 3.03 & 1.35 & & & & \\
\hline Algilanan & 6. sinıf & 66 & 3.76 & 0.79 & $2-194$ & 14.47 & 0.000 & 0.130 \\
etkililik & 7. sinif & 63 & 3.89 & 0.68 & & & & \\
& 8. sinıf & 68 & 3.07 & 1.25 & & & & \\
\hline Algilanan & 6. sinif & 66 & 3.07 & 1.21 & $2-194$ & 3.41 & 0.035 & 0.034 \\
negatif & 7. sinif & 63 & 2.74 & 1.24 & & & & \\
etkiler & 8. sinif & 68 & 3.32 & 1.35 & & & & \\
\hline Toplam & 6. sinif & 66 & 3.81 & 0.70 & $2-194$ & 17.38 & 0.000 & 0.152 \\
puan & 7. sinif & 63 & 3.78 & 0.67 & & & & \\
& 8. sinif & 68 & 3.00 & 1.21 & & & & \\
\hline
\end{tabular}

Tablo 6'da bağımsız değişkenlerin sınıf düzeyine göre anlamlı düzeyde farklılaşıp farklılaşmadıklarına ilişkin veriler sunulmuştur. Algılanan öğrenmeye katkı ve motivasyon $\left(\mathrm{F}_{(2,194)}=15.50, \mathrm{p}=0.000\right.$, Partial eta squared $\left.=0.138\right)$, algilanan etkililik $\left(\mathrm{F}_{(2,194)}=14.47, \mathrm{p}=0.000\right.$, Partial eta squared $=0.130)$, algilanan negatif etki $\left(\mathrm{F}_{(2,194)}=3.41, \mathrm{p}<0.05\right.$, Partial eta squared $\left.=0.034\right)$ ve toplam puan $\left(\mathrm{F}_{(2,194)}=17.38, \mathrm{p}=0.000\right.$, Partial eta squared $\left.=0.152\right)$ bağımlı değişkenlerinin dördü açısından da öğrenim görülen sınıf düzeyine göre anlamlı farklılaşmanın olduğu tespit edilmiştir.

Farkın kaynağına ilişkin yapılan Bonferroni testi sonucuna göre, algılanan öğrenmeye katkı ve motivasyon değişkeni, algılanan etkililik değişkeni ve toplam puan açısından 8. sınıf öğrencileri 6 . ve 7. sınıf öğrencilerine göre anlamlı düzeyde düşük puana sahiptirler $(\mathrm{p}<0.05)$. Algılanan negatif etki değişkeni açısından ise 7. sınıf ile 8. sınıf öğrencileri arasında anlamlı farklılık vardır $(p<0.05) . \mathrm{Bu}$ 
boyuta ilişkin ortalama puanlara bakıldığında 8. sınıf öğrencilerinin 7. sınıf öğrencilerine kıyasla daha yüksek puanlara sahip oldukları görülmüştür.

Etkileşimli Tahta ile Öğrenme Algısı ve Alt Boyutlarının etkileşimli Tahtanın Haftalık Kullanım Süresine Göre Karşılaştırılmasina İliş̧kin Bulgular.

Etkileşimli tahtanın haftalık kullanım süresi ile etkileşimli tahta ile öğrenme algısı puanı ve alt faktörlerine göre farklılaşma durumu için gerçekleştirilen MANOVA testi sonucuna göre bağımlı değişkenlerin ortak etkisine göre anlamlı farkl1lı tespit edilmiştir $\left(\mathrm{F}_{(12,502)}=3.63, \mathrm{p}=0.000\right.$; Wilks' $\operatorname{Lambda}(\wedge)=0.80$; Partial eta squared $=0.071)$.

Tablo 7

Etkileşimli Tahta ile Öğrenme Algısı Toplam Puanı ve Alt Faktör Puanlarının Haftalık etkileşimli Tahta Kullanım Süresine Göre Ortalama, Standart Sapma Değerleri ve ANOVA Sonuçları

\begin{tabular}{lllllllll}
\hline & Haftalı & $\mathrm{N}$ & $\bar{x}$ & $\mathrm{Ss}$ & $\mathrm{Sd}$ & $\mathrm{F}$ & $\mathrm{p}$ & Partial eta squared \\
kullanım & & & & & & & \\
\hline Algilanan & 1 saatten az & 57 & 2.97 & 1.33 & $4-192$ & 7.64 & 0.000 & 0.137 \\
ögrenmeye & 1-3 saat & 60 & 3.84 & 1.01 & & & & \\
katk1 ve & 4-5 saat & 30 & 4.06 & 0.69 & & & & \\
motivasyon & 6-7 saat & 33 & 3.72 & 1.01 & & & & \\
& 8 saatten fazla & 17 & 3.86 & 0.82 & & & & \\
\hline Algilanan & 1 saatten az & 57 & 3.00 & 1.32 & $4-192$ & 8.15 & 0.000 & 0.145 \\
etkililik & 1-3 saat & 60 & 3.82 & 0.81 & & & & \\
& 4-5 saat & 30 & 3.99 & 0.48 & & & & \\
& 6-7 saat & 33 & 3.58 & 0.79 & & & & \\
\hline Algilanan & 8 saatten fazla & 17 & 3.84 & 0.65 & & & & \\
negatif & 1-3 saatt & 60 & 3.07 & 1.29 & & & & \\
etkiler & 4-5 saat & 30 & 3.36 & 1.19 & & & & \\
& 6-7 saat & 33 & 3.07 & 1.02 & & & & \\
\hline Toplam & 8 saatten fazla & 17 & 2.69 & 1.28 & & & & \\
puan & 1-3 saatten az & 57 & 2.98 & 1.26 & $4-192$ & 7.40 & 0.000 & 0.134 \\
& 4-5 saat & 60 & 3.73 & 0.81 & & & & \\
& 6-7 saat & 30 & 3.88 & 0.47 & & & & \\
\hline
\end{tabular}

Bağımlı değişkenlerin, etkileşimli tahta ile öğrenme algısı puanlarının ayrı ayrı değerlendirildiği Tablo 7'ye bakıldığında, algılanan negatif etki değişkenine göre anlamlı farklılaşma görülmemiştir $\left(\mathrm{F}_{(4,192)}=0.81, \mathrm{p}=0.052\right.$, Partial eta squared $\left.=0.017\right)$. Alg1lanan öğrenmeye katk1 ve motivasyon $\left(\mathrm{F}_{(4,192)}=7.64, \mathrm{p}=0.000\right.$, Partial eta squared $\left.=0.137\right)$; Algilanan etkililik $\left(\mathrm{F}_{(4,192)}=8.15, \mathrm{p}=0.000\right.$, Partial eta squared $=0.145)$ ve toplam puan $\left(\mathrm{F}_{(4,192)}=7.40, \mathrm{p}=0.000\right.$, Partial eta squared $\left.=0.134\right)$ açısından anlaml farklılaşmanın olduğu görülmektedir. Yapılan Bonferroni çoklu karşılaştırma testi sonucuna göre, etkileşimli tahtanın haftalık 1 saatten az kullanıldığı sınıflarda eğitim alan öğrencilerin algılanan ögrenmeye katkı ve motivasyon puanları, 1-3 saat, 6-7 saat ve 8 saatten fazla kullanımın olduğu ögrencilerle anlamlı düzeyde farklılaşmaktadır $(\mathrm{p}<0.05)$ ve diğer üç gruptan daha düşüktür. Algılanan etkililik puanına göre ise haftalık 1 saatten az kullanımın olduğu sınıflardaki öğrencilerin haftalık 1-3 saat, 4-5 saat ve 8 saatten fazla kullanımın olduğu öğrencilerle anlamlı düzeyde farklılaştığı görülmüştür $(\mathrm{p}<0.05)$. Algılanan etkililik açısından haftalık 1 saatten az etkileşimli tahta kullanımının olduğu öğrencilerin puanları diğer üç gruptan anlamlı düzeyde düşüktür. Etkileşimli tahta ile öğrenme algısı ortalama puanı için ise etkileşimli tahtanın haftalık 1 saatten az kullanıldığı öğrencilerde diğer dört gruptan (1-3 saat, 4-5 saat, 6-7 saat ve 8 saatten fazla) anlamlı düzeyde farklılaştığı $(\mathrm{p}<0.05)$ ve daha düşük olduğu görülmüştür. 
Etkileşimli Tahta ile Öğrenme Algısı ve Alt Boyutlarının etkileşimli Tahta ile Eğitim Alınma Süresine Göre Karşılaştırılmasına İlişkin Bulgular.

Kaç yıldır etkileşimli tahta ile eğitim alındığı ile etkileşimli tahta ile öğrenme algısı puanı ve alt faktörleri arasında yapılan tek yönlü gruplar arası çok değişkenli varyans analizi sonucuna göre anlamlı fark bulunmamıştır $\left(\mathrm{F}_{(15,519)}=1.154, \mathrm{p}>0.05\right.$; Wilks' Lambda $(\wedge)=0.91$; Partial eta squared $\left.=0.033\right)$. Etkileşimli tahta ile öğrenme algısı toplam puanı ve ölçeğin alt faktör ölçümlerinin ortak etkisine göre öğrencilerin etkileşimli tahta ile eğitim alma süreleri anlamlı düzeyde farklılaşmamaktadır. Benzer şekilde algılanan öğrenmeye katkı ve motivasyon, algılanan etkililik, algılanan negatif etkiler ve toplam puan ölçümleri bağımsız olarak analize tabi tutulduğunda da etkileşimli tahta ile eğitim alınma süresi açısından anlamlı farklılaşma olmamaktadır.

Tablo 8

Öğrencilerin Kaç Yıldır Etkileşimli Tahta Kullandığına Yönelik Cevapların Betimsel İstatistikleri

\begin{tabular}{lrr}
\hline Etkileşimli tahta kullanım yılı & $\mathrm{N}$ & $\%$ \\
\hline 1y1l & 153 & 78.06 \\
$2 \mathrm{y} 1 \mathrm{l}$ & 23 & 11.73 \\
3y1l & 10 & 5.10 \\
4y1l & 4 & 2.04 \\
5y11 & 2 & 1.02 \\
6y1l & 4 & 2.04 \\
\hline Toplam & 196 & 100 \\
\hline
\end{tabular}

Tablo 8 incelendiğinde çalı̧̧maya katılan öğrencilerin etkileşimli tahta ile son yıllarda tanıştıkları anlaşılmaktadır. Büyük çoğunluğunun ise (\%78.06) etkileşimli tahtayı bir yıldır kullandıkları görülebilir.

\section{Sonuç ve Öneriler}

Eğitim teknolojisi araçlarının sınıf ortamına girişi eski tarihlere dayanmakla birlikte bilgi sunumu için kullanılan ve ilkler arasında yer alan tahtalar, bilgisayar teknolojisindeki gelişmeler ile günümüzde etkileşimli tahtalar biçimini almışıı. Etkileşimli tahtalara yapılan yatırımların maliyeti yüksek olmakla birlikte, sunduğu özellikler bakımından dünya çapında tercih edilmektedir. FATİH projesi kapsamında okullarda yer alan yüz binlerce etkileşimli tahta ve tablet bilgisayarların teknolojiyle öğrenme firsatı sunması oldukça değerli görülmekle birlikte bu konuda yapılacak akademik çalışmalar ve pratikler önemlidir. Etkileşimli tahtalar ile ilgili yapılacak bilimsel araştırmalarla bu alandaki problemlere çözüm aranmasının eğitim sistemine katkı getireceği düşünülmektedir. Bu çalışmada ortaokul öğrencilerinin etkileşimli tahta kullanımına yönelik duyuşsal özelliklerden tutum ve etkileşimli tahta ile öğrenme algısı değişkenlerinin cinsiyet, sınıf, öğrenci deneyimi ve sınıf deneyimi değişkenlerine göre farklılaşma durumlarının ortaya koyulması amaçlanmıştır.

Araştırma sonuçlarına göre, etkileşimli tahtaya yönelik olumsuz tutum cinsiyete göre anlamlı farklıl1k gösterirken olumlu tutum ve toplam tutumda anlamlı bir fark bulunmamıştır. Ortalama puanlar göz önünde bulundurulduğunda olumsuz tutum ortalamalarının erkeklerde kızlara göre anlamlı düzeyde daha yüksek olduğu görülmüştür. Benzer biçimde Aytaç (2013) kız öğrencilerin daha yüksek düzeyde olumlu tutuma sahip olduğu sonucuna ulaşmıştır. Bir diğer çalışmada erkek öğrencilerin anlamlı düzeyde daha fazla olumlu tutuma sahip olduğu sonucuna ulaşılmıştır (Balta ve Duran, 2015). Cinsiyete göre etkileşimli tahtaya yönelik tutumun değişmediği de araştırma sonuçları arasında yer almaktadır (Demircioğlu ve Demircioğlu, 2015; Korucu, Usta ve Toraman, 2016).

Sınıf değişkenine göre olumlu tutum alt faktörü ve toplam tutum için anlamlı farklılaşmaların olduğu tespit edilmiştir. Her iki ölçüm için de 6 . sınıf öğrencilerinin ölçümleri daha yüksektir ve 8 . sınıf öğrencilerinden anlamlı biçimde farklılaşmaktadır. Sınıf düzeyi arttıkça olumlu tutum azalmaktadır. Benzer sonuçlara Demircioğlu ve Demircioğlu (2015) ile Korucu, Usta ve Toraman'ın (2016) çalışmasında rastlanmıştır. Bu sonuçtan hareketle, öğretim esnasında etkileşimli tahta kullanırken üst sınıflarda öğrenim gören öğrencilerin tutumlarının daha düşük olması durumunun hatırlanması, öğretmenler için önemli bir bilgidir.

Kullanım süresi bakımından araştırma sonuçlarına göre haftada bir saatten az etkileşimli tahta 
kullanımının olduğu öğrencilerin diğer üç gruba (1-3 saat arası, 4-5 saat arası ve 8 saatten fazla) göre olumlu tutumları düşüktür. Benzer şekilde haftalık bir saatten az eğitim alan öğrencilerin genel tutumları geri kalan diğer dört gruptan anlamlı biçimde düşüktür. Haftada bir saatten az etkileşimli tahta kullanımının olduğu öğrencilerin olumlu yöndeki tutumları ve genel tutumları daha fazla kullanımın olduğu öğrencilere göre düşüktür. Aytaç’a (2013) göre, öğrencilerin etkileşimli tahta kullanımlarının artması olumlu tutumlarının artmasına neden olmaktadır ve bu durum çalışma kapsamında elde edilen bulgularla paralellik göstermektedir. FATIH projesi kapsamında etkileşimli tahtaların gün geçtikçe okullarda yaygınlaştığ 1 ülkemizde bu bulgudan hareketle öğretmenlerden ziyade öğrencilerin söz konusu teknolojiyi sınıflarda daha sık kullanmaları önerilmektedir. Öğrencilerin en çok etkileşimli tahta kalemini kullanmakta zorluk çektiği ifade edilmekte (Sunkur, Şanlı ve Arabacı, 2011) ve bu teknolojiyi kullanımları konusunda eğitim almaları önerilmektedir (Çoklar ve Tercan, 2014; Keser ve Çetinkaya, 2013).

Etkileşimli tahtaya yönelik tutum ve alt boyutları, etkileşimli tahta ile eğitim alma süresine göre anlamlı düzeyde farklılaşmamaktadır. Beauchamp ve Kennewell (2013) etkileşimli tahtaların eğitsel kullanımına yönelik stratejilere işaret etmiş, öğrenciyi destekleyici stratejilere odaklanılması gerektiğini önermiştir. Ayrıca öğretmenlerin etkileşimli tahta ile ilgili alanlarına özel eğitim almaları bu teknolojinin etkileşim özeliklerini kullanımını artırmaktadır (Tatli ve Kiliç, 2015). Öğrenciler etkileşimli tahtaya yönelik genel olarak olumlu tutum sergilemekle birlikte bu aracın motivasyon ve sınıf etkileşimini artırdığını ifade edilmektedir (Şad ve Özhan, 2012). İletişim ve etkileşimin önemli bir yer tuttuğu öğretim ortamında, etkileşimli tahtaların öğrencileri temel alan etkinliklerle kullanılması ile sınıf içerisindeki dijital teknolojiye yönelik öğrenci tutumu süreç içerisinde olumlu etkilenebileceği düşünülmektedir.

Etkileşimli tahta ile öğrenme algısı ile ilgili olarak, algılanan öğrenmeye katkı ve motivasyon, algılanan etkililik ve bu değişkenlere ilişkin toplam puan cinsiyete göre anlamlı düzeyde farklılaşmamaktadır. Algılanan negatif etkiler boyutu açısından ise kız ögrenciler erkeklere göre daha yüksek düzeyde negatif etki algılamaktadırlar. Bu çalışma kapsamındaki bulgular erkek öğrencilerin olumsuz tutumlarının daha fazla olduğunu ortaya koymuştur. Bu iki bulgu birbiriyle çelişiyor gibi gözükebilir. Fakat kız öğrenciler, etkileşimli tahta kullanımı esnasında sınıf düzeninin bozulması, teknik aksaklıkların yaşanması gibi durumları yansıtan algılanan negatif etkiler noktasında erkek öğrencilerden farklılaşmaktadırlar ve bu konuda daha duyarlı oldukları söylenebilir. Sonuç olarak kız öğrencilerin etkileşimli tahtaya ilişkin olumsuz tutumları erkeklere göre daha az olmakla birlikte, bu teknolojinin kullanımı sürecinde yaşanan aksaklıklara karşı daha duyarlıdırlar.

Sınıf düzeyi açısından etkileşimli tahta ile öğrenme algısı ve tüm alt boyutlarına ilişkin anlamlı farklılıklar tespit edilmiştir. Algılanan öğrenmeye katkı ve motivasyon, algılanan etkililik ve toplam puan açısından 8. sınıf ögrencileri ile 6. ve 7. sınıf öğrencilerine göre anlamlı düzeyde düşük algıya sahiptirler. Algılanan negatif etki açısından ise 8. sınıf öğrencileri 7. sınıf öğrencilerine göre daha yüksek düzeyde negatif algıya sahiptirler. Bu bulgular, 8. sınıf öğrencilerinin etkileşimli tahta ile öğrenme algılarının diğerlerine göre daha olumsuz olması durumunu ortaya koymaktadır. Ortaya konulan sonuçlar lise öğrencileri ile gerçekleştirilen bir araştırma sonuçlarına paraleldir (Öz, 2015). Yapılacak yeni çalışmalarda, ortaokul 8. sınıf öğrencilerinin farklılaşan bu durumlarının nedenleri araştırılabilir.

Etkileşimli tahta ile haftalık 1 saatten az eğitim alan öğrencilerin algılanan öğrenmeye katkı ve motivasyonları, 4-5 saat öğrenim gören öğrenciler haricindeki diğer üç gruba nazaran anlamlı bir biçimde daha düşüktür. Algılanan etkililik durumuna göre ise haftalık 1 saatten az eğitim alan öğrencilerin haftalık 6-7 saat öğrenim gören öğrenciler hariç diğer üç gruptan anlamlı düzeyde düşük algıya sahiptirler. Etkileşimli tahta ile öğrenme algısının geneli için ise etkileşimli tahta ile haftalık 1 saatten az eğitim alan öğrencilerin diğer dört gruptan (1-3 saat, 4-5 saat, 6-7 saat ve 8 saatten fazla) anlamlı biçimde farklılaştı̆̆ 1 ve daha düşük olduğu görülmüştür. Dolayısıyla etkileşimli tahta ile bir saatten az eğitim alan öğrenciler etkileşimli tahta ile öğrenmeye karşı olumlu alg1 noktasında diğer gruplara kıyasla daha düşük düzeydedirler. Benzer bir çalışmada algılanan öğrenme, algılanan etkililik ve genel algı, etkileşimli tahtayı daha fazla kullana öğrencilerin lehine anlamlı farklılık göstermektedir (Öz, 2014). Öğrencilerin etkileşimli tahta ile ilgili kendi deneyimleri öğrenmeye ilgi ve isteklerini artırmaktadır (Luo ve Yang, 2016).

Kullanım süresine göre etkileşimli tahta ile öğrenme algısı ölçümleri anlamlı biçimde farklılaşmamaktadır. Tutum değişkeni ve alt boyutları için de paralel sonuçlar bulunmuş ve anlamlı farklılık bulunmamıştır. Bu çalışma kapsamında elde edilen betimsel bulgulardan, öğrencilerin 
etkileşimli tahta ile ağırlıklı olarak son yıllarda tanıştıkları görülmüştür (bkz. Tablo 8). Etkileşimli tahtaların son zamanlarda yaygınlaşması göz önünde bulundurulduğunda bu sonucun yanıltıcı olma durumu söz konusu olabilir. Etkileşimli tahtanın eğitim hayatında kullanım süresi hususunda yapılacak karşılaştırmaların ilerleyen yıllarda tekrar edilmesi önerilmektedir. Böylelikle daha sağlıklı sonuçlar elde edilmesi muhtemeldir.

Bundan sonra yapılacak araştırmalarda etkileşimli tahta ile ilgili duyuşsal özellikleri etkileyen değişkenler ve bunların etkilediği öğrenme ile ilgili değişkenler üzerinde çalışmalar yapılabilir. Öğretmen, öğrenci ve yöneticilerin bu teknolojiyle ilgili duyuşsal diğer özellikleri araştırılabilir. Çalışmanın lise, üniversite ve öğretmen adayları ile diğer öğrenci gruplarıyla tekrarlanması önerilmektedir. Etkileşimli tahtanın pedagojik etkileri üzerine çalışmaların yapılması önerilmektedir. Farklı sınıf ve deneyime sahip öğrencilerin etkileşimli tahtaları etkili kullanmalarına yönelik çeşitli etkinlikler planlanmalıdır. Yeniliğin devamlı aynı etkiyi bırakacağı düşüncesinden uzaklaşılmalı, öğrenme etkinlikleri de yeniliklere paralel biçimde geliştirilmelidir. FATïH projesi kapsamında kurulumu yapılan etkileşimli tahtalar tabletlerle birlikte kullanılmaya başlanmıştır. Gerçekleştirilen öğrenme etkinlikleri esnasında bu teknoloji yoğun ortama yönelik öğrencilerin duyuşsal özelliklerini kapsayan araştırmalara yer verilmelidir.

\section{Kaynaklar}

Adıgüzel, T., Gürbulak, N. ve Sarıçayır, H. (2011). Akıllı tahtalar ve öğretim uygulamaları. Mustafa Kemal Üniversitesi Sosyal Bilimler Enstitüsü Dergisi, 8(15), 457-471.

Akgün, M. ve Koru, G. (2015). Akıllı tahta kullanımına yönelik öğrenci tutumu ve öğretmen görüşlerinin incelenmesi (Ankara ili örneği). Qualitative Studies, 1, 1-12.

Albayrak, E., Güngören, Ö. C. ve Horzum, M. B. (2014). Algılanan öğrenme ölçeğinin Türkçe’ye uyarlaması. Ondokuz Mayıs Üniversitesi Eğitim Fakültesi Dergisi, 33(1), 1-14.

Aytaç, T. (2013). Interactive white board factor in education: Students' points of view and their problems. Educational Research and Reviews, 8(20), 1907-1915.

Balta, N. ve Duran, M. (2015). Attitudes of students and teachers towards the use of interactive white boards in elementary and secondary school classrooms. TOJET: The Turkish Online Journal of Educational Technology, 14(2), 15-21.

Baylor, A. L. ve Ritchie, D. (2002). What factors facilitate teacher skill, teacher morale, and perceived student learning in technology-using classrooms?.Computers \&Education, 39(4), 395-414.

Beauchamp, G. ve Kennewell, S. (2013). Transition in pedagogical orchestration using the interactive white board. Education and Information Technologies, 18(2), 179-191.

Cabı, E. (2016). Dijital teknolojiye yönelik tutum ölçeği. Kastamonu Eğitim Dergisi, 24(3), 875-890.

Cakir, R. ve Yildirim, S. (2009). What do computer teachers think about the factors affecting technology integration in schools. Ilkögretim Online, 8(3), 952-964.

Çakıroğlu, Ö. (2016). Students' views on theuse of interactive white boards in the secondary schools for enhancing classrooms learning. Bayburt Ĕ̈itim Fakültesi Dergisi, 11(2),615-632.

Çoklar, A. N. ve Tercan, İ. (2014). Opinions of teachers toward the use of smart boards. Elementary Education Online, 13(1), 48-61.

Davis, F. D. (1989). Perceived usefulness, perceived ease of use, and user acceptance of information technology. MIS quarterly, 319-340.

Demircioğlu, G. ve Demircioğlu, H. (2015). Öğrencilerin kimya derslerinde etkileşimli tahta kullanımına yönelik tutumlarının farklı değişkenler açısından incelenmesi. Ĕgitim ve Öğretim Araştırmaları Dergisi, 4(2), 387-395.

DiGregorio, P. ve Sobel-Lojeski, K. (2010). The effects of interactive white boards (IWBs) on student performance and learning: A literature review. Journal of Educational Technology Systems, $38(3), 255-312$.

Greiffenhagen, C. (2002). Out of the Office into the school: electronic white boards for education. Erişim adresi: http://www.cs.ox.ac.uk/techreports/oucl/TR-16-00.pdf

Gündoğdu, T. (2014). Bir öğretme-öğrenme aracı olarak akıllı tahta. Akademik Sosyal Araştırmalar Dergisi, 2(6), 392-401.

Gömleksiz, M. N. ve Kan, A. Ü. (2012). Eğitimde duyuşsal boyut ve duyuşsal öğrenme. Turkish Studies, 7(1), 1159-1177.

İnceoğlu, M. (2010). Tutum algı iletişim. Ankara: Beykent Üniversitesi Yayınevi. 
Karasar, N. (2005). Bilimsel araştırma yöntemi (14. Baskı). Ankara: Nobel Yayın Dağıtım.

Kaya, H. ve Aydın, F. (2011). Sosyal bilgiler dersindeki coğrafya konularının öğretiminde akıllı tahta uygulamalarına iliş̧kin öğrenci görüşleri. Zeitschriftfürdie Welt der Türken/Journal of World of Turks, 3(1), 179-189.

Keser, H. ve Çetinkaya, L. (2013). Öğretmen ve öğrencilerin etkileşimli tahta kullanımına yönelik yaşamış oldukları sorunlar ve çözüm önerileri. Electronic Turkish Studies, 8(6), 377-403.

Korucu, A. T., Usta, E. ve Toraman, L. (2016). Ortaokul öğrencilerinin etkileşimli tahta kullanımına yönelik tutumlarının farklı değişkenler açısından incelenmesi. Bartın Üniversitesi Eğitim Fakültesi Dergisi, 5(3), 690-717.

Kelecioğlu, H. (1992). Güdülenme. Hacettepe Üniversitesi Eğitim Fakültesi Dergisi, 7(7), 175-181.

Levy, P. (2002) Interactive white boards in learning and teaching in two Sheffield schools: a developmental study. Erişim adresi: http://www.shef.ac.uk/eirg/projects/ wboards.

Lumsden, L. S. (1994). Student motivation to learn. ERIC Digest, Number 92.

Luo, Y. F. ve Yang, S. C. (2016). Theeffect of theinteractive functions of white boards on elementary students' learning. Journal of Educational Computing Research, 0735633115628032.

Mercer, N., Warwick, P., Kershner, R. ve Kleine Staarman, J. (2010). Can the interactive white board help to provide a 'dialogic space' for children's collaborative activity? Language and Education, 24(5), 367-384.

MEB (2015a). FATIH Projesi bir tablet projesi değil, ulusal bir eğitim projesidir. Erişim adresi:http://www.meb.gov.tr/fatih-projesi-bir-tablet-projesi-degil-ulusal-bir-egitim-projesidir/ haber/8221/tr

MEB (2015b). 2015-2016 öğretim y1lı akıllı tahta ile başladı. Erişim adresi: http://izmitfarabioo.meb.k12.tr/icerikler/2015-2016-ogretim-yili-akilli-tahta-ile-basladi_ 2065249. html

Moss, G., Jewitt, C., Levaãiç, R., Armstrong, V., Cardini, A. ve Castle, F. (2007). The interactive white boards, pedagogy and pupil performance evaluation. Erişim adresi: www.dfes.gov.uk/ research/data/uploadfiles/RR816.pdf

Öz, H. (2014). Teachers' and students' perceptions of interactive white boards in the English as a foreign language classroom. TOJET: The Turkish Online Journal of Educational Technology, 13(3), 156-177.

Saadé, R. ve Bahli, B. (2005). The impact of cognitive absorption on perceived usefulness and perceived ease of use in on-line learning: An extension of the technology acceptance model. Information \& Management, 42(2), 317-327.

Schmid, E. C. (2008). Potential pedagogical benefits and drawbacks of multimedia use in the English language classroom equipped with interactive white board technology. Computers \& Education, $51,1553-1568$.

Smith, L. (2008). An investigation into the effect of a NATE/Becta training programme on the use of interactive white boards in teaching and learning in secondary english. English in Education, 42(3), 269-282.

Somyürek, S., Atasoy, B. ve Özdemir, S. (2009). Board's IQ: What makes a board smart?. Computers \& Education, 53(2), 368-374.

Sunkur, M. Şanlı, Ö. ve Arabacı İ. B. (2011). Akıllı tahta uygulamaları konusunda ilköğretim II. kademe öğrencilerinin görüşleri (Malatya ili örneği). 5. Uluslararası Bilgisayar ve Öğretim Teknolojileri Sempozyumu. Firat Üniversitesi, Elazığ, Turkey.

Şad, S. N. (2012). An attitude scale for smart board use in education: Validity and reliability studies. Computers \& Education, 58(3), 900-907.

Şad, S. N. ve Özhan, U. (2012). Honeymoon with IWBs: A qualitative insight in primary students' views on instruction with interactive white board. Computers \& Education, 59(4),1184-1191.

Tatli, C. ve Kiliç, E. (2015). Interactive white boards: Do teachers really use them interactively?, Interactive Learning Environments, DOI: 10.1080/10494820.2015.1016536

Torff, B. ve Tirotta, R. (2010). Interactive white boards produce small gains in elementary students' self-reported motivation in mathematics. Computers\&Education, 54(2), 379-383.

Tosuntaş, Ş. B., Karadağ, E. ve Orhan, S. (2015). The factors affecting acceptance and use of interactive white board within the scope of FATIH project: A structural equation model based on the Unified Theory of acceptance and use of technology. Computers \& Education, 81, 169-178. 
TRT (2016). 58 bin sınıf daha "akıllı tahta"ya kavuşuyor. Erişim adresi: http://www.trthaber.com/ haber/egitim/58-bin-sinif-daha-akilli-tahtaya-kavusuyor-239701.html

Türel, Y. K. (2011). An interactive white board student survey: Development, validity and reliability. Computers \& Education, 57(4), 2441-2450.

Venkatesh, V. (2000). Determinants of perceive dease of use: Integrating control, intrinsic motivation, and emotion into thetechnology acceptance model. Information Systems Research, 11(4), 342365.

Wall, K., Higgins, S. ve Smith, H. J. (2005). The visual helps me understand the complicated things: Pupil views of teaching and learning with interactive white boards. British Journal of Education Technology, 36(5), 851-867.

Yang, H. D. ve Yoo, Y. (2004). It's all about attitude: revisiting the technology acceptance model. Decision Support Systems, 38(1), 19-31.

\section{Extended Abstract}

\section{Introduction}

While use of instruments of information and communication technologies in classroom environment is becoming highly prevalent around the world, interactive whiteboards indicate a significant place in ICT integration process in Turkish educational system (Somyürek, Atasoy \& Özdemir, 2009). By means of FATIH project, the number of classrooms with interactive whiteboard in our country has reached almost 300 thousand (TRT, 2016). Compared to traditional boards, interactive whiteboards provide various opportunities for learning environment. Interactive whiteboards are preferred by teachers and students as these whiteboards aid students' participation into classroom, affect success (Torf \& Tirotta, 2010), attract attention, provide excitement and help with providing motivation (Schmid, 2008), and support better comprehension of lecture (Kaya \& Aydın, 2014).

Affective qualities have an important place in use of technology in education (Venkatesh, 2000; Yang \& Yoo, 2004). While various models are suggested in process of integration of technology, students' affective characteristics such as attitude, motivation and perception are critical (Türel, 2011). The studies that reveal students' opinions concerning interactive whiteboards are especially limited (Aytaç, 2013). The scarcity of studies particularly conducted with secondary school students and with demographic variables, period of use and usage experience has become the primary reason for conducting this study.

The aim of this study was to reveal differentiation of attitude, perceived learning and motivation, perceived effectiveness and perceived negative effects variables from affective features for interactive whiteboards use, from variables of gender, grade, student experience, and interactive whiteboard usage period.

\section{Method}

Students having education in two private secondary schools in Ankara Province participated into the study conducted with survey model. Analyses were conducted with the data obtained from 197 students in total. 80 of participants were female and 117 were male. $66(33.5 \%)$ of them were studying in $6^{\text {th }}$ grade, $63(32 \%)$ of them were studying in $7^{\text {th }}$ grade and $68(34.5 \%)$ of them were studying in $8^{\text {th }}$ grade.

Interactive Whiteboard Attitude Scale, developed by Şad (2012), was used in an attempt to determine participants' attitude towards interactive whiteboard. First factor in the scale covers negative attitude expressions and second factor covers positive attitude expressions. Three-factor scale, developed by Türel (2011), was used in order to determine students' learning perception with interactive whiteboard. These factors are Contribution and Motivation to Perceived Learning, Perceived Effectiveness and Perceived Negative Effects. MANOVA was used in data analysis.

\section{Result and Discussion}

According to study results, negative attitude towards interactive whiteboard differentiated in accordance with gender. Positive attitude measurements changed according to grade; and were lower in students who use interactive whiteboards less than one hour per week in terms of usage period. In terms of general attitude, measurements differentiated in terms of grade level variable and usage period variables. There was also a difference observed in weekly education period taken with interactive whiteboard from the 
point of the other three measurements other than the perceived negative effects. There was no significant difference both in terms of the attitude measurements and the learning perception measurements by means of interactive whiteboards with regard to usage period (year) of interactive whiteboards.

It was observed that negative attitude averages are significantly higher among males than females. This differentiating situation of male students from female students should be taken into consideration while learning activities are being prepared. It is crucial information for teachers to keep in mind that students of higher grades have a lower average of attitude while using interactive whiteboard for learning. Students who use interactive whiteboard less than one hour in a week have a lower level of positive attitude and general attitude compared to students who use interactive whiteboard more often. Attitude towards use of interactive whiteboard and its sub-dimensions differentiates depending on the period of education with interactive whiteboard. In education environment where communication and interaction take up an important place, students' attitude towards digital technology in classroom within the process will be positively affected by use of interactive whiteboards in students' basic field activities.

In terms of interactive whiteboard and its contribution to learning perception, perceived contribution and motivation to the perceived learning, perceived effectiveness and total score concerning these variables do not differ depending on gender. With regard to perceived negative effects dimension, female students perceive a higher level of negative effect compared to male students. While negative attitude of female students concerning interactive whiteboard is lower, they are more sensitive towards malfunctioning experienced in the process of using this technology. $8^{\text {th }}$ grade students have a significantly lower perception level in terms of perceived contribution and motivation to perceived learning, perceived effectiveness and total score compared to $6^{\text {th }}$ grade and $7^{\text {th }}$ grade students. In terms of perceived negative effect, $8^{\text {th }}$ grade students have a higher level of negative perception compared to $7^{\text {th }}$ grade students. These findings indicate that $8^{\text {th }}$ grade students have a more negative learning perception by means of interactive whiteboard than the others. In future studies, reasons for $8^{\text {th }}$ grade students' differentiating situation can be studied.

Students who receive education less than one hour with interactive whiteboard have a lower level of positive perception than other groups in terms of learning by means of interactive whiteboard. Learning perception through interactive whiteboard does not differ based on the usage period of interactive whiteboard. Parallel results were found for the variable of attitude and its sub-dimensions and no significant difference was found. Considering the recent prevalence of interactive whiteboards, this result might be misleading. It is recommended that comparisons concerning usage period of interactive whiteboards in educational life are repeated in following years.

Future studies can be conducted on the variables that have an impact on affective qualities concerning interactive whiteboard and the variables regarding learning which is affected by the former variables. It is suggested that similar studies are repeated at high school and with preservice teachers and other student groups in university. Studies to be conducted on pedagogical effects of interactive whiteboards are suggested. Various activities should be planned for effective use of interactive whiteboards by students of different grade, gender and experience. The idea that novelty always leaves the same impression should be abandoned, and learning activities should be developed in parallel with novelties. 